\title{
Plano Diretor Municipal da Golegã: uma abordagem de base-local
}

\author{
Golegã's Master Plan: a local-based approach
}

\section{Plan Maestro Municipal de Golegã: un enfoque de base-local}

Carlos Almeida Marques, Arquiteto e Urbanista, Doutorado em Administração Pública Instituto Superior de Ciências Sociais e Políticas da Universidade de Lisboa (ISCSP-UL) e Medio Ambiente (Universidad Complutense de Madrid), Investigador do Centro de Investigação em Arquitectura, Urbanismo e Design - Faculdade de Arquitectura da Universidade de Lisboa (CIAUD-FAUL) e Centro de Administração e Políticas Públicas-Instituto Superior de Ciências Sociais e Políticas da Universidade de Lisboa (CAPP-ISCSP-UL).

E-mail: camarques@caam.com.pt（iD) ORCID: https://orcid.org/0000-0002-0592-6537

Para citar este artigo: MARQUES, C. A. Plano diretor municipal da Golegã: uma abordagem de base-local. Cadernos de Pós-Graduação em Arquitetura e Urbanismo, São Paulo, v. 22, n.1, p. 08-31, 2021. DOI 10.5935/ cadernospos.v22n1p08-31

Submissão: 2021-09-25

Aceite: $2021-10-22$

\section{Resumo}

Neste artigo, propomos abordar, como parte da solução e suporte da tomada de decisões populares, a participação pública e a sua relação com o planejamento regional e urbano. $\mathrm{O}$ texto foi organizado em duas partes: a primeira dedica-se ao enquadramento teórico e conceptual das políticas e mecanismos participativos; na segunda, apresenta-se um caso concreto de implementação de processos participativos - designadamente, a Metodologia 
Q - no âmbito do projeto de revisão do Plano Diretor Municipal da Golegã. Essa estratégia, além de favorecer o exercício da cidadania e a governança territorial, contribui para que o Plano seja apropriado pela comunidade local como "seu Plano".

Palavras-chave: Plano; Participação; Governança; Território; Políticas públicas.

\begin{abstract}
In this article we propose to address the theme of public participation and its relationship with regional and urban planning, understood as part of the solution and support of decision making. The text was organized in two parts: the first dedicated to the theoretical and conceptual framework of participatory policies and mechanisms; in the second part a concrete case for the implementation of participatory processes, namely the $Q$ Methodology, is presented, within the context of the Golegã's Municipal Master Plan draft revision. The implementation of participatory processes, in addition to promoting the exercise of citizenship and territorial governance, contribute to the taking by local community of the Plan as "their Plan".
\end{abstract}

Keywords: Plan; Participation; Governance; Territory; Public policy.

\title{
Resumen
}

En este artículo proponemos abordar el tema de la participación pública y su relación con la planificación regional y urbana, entendida como parte de la solución y apoyo a la toma de decisiones. El texto se organizó en dos partes: la primera dedicada a los conceptos teóricos y conceptuales sobre políticas y mecanismos participativos; en la segunda parte se presenta un caso de implementación de procesos participativos, a saber, la Metodología Q, en el contexto del proyecto de revisión del Plan Maestro Municipal de Golegã. La implementación de procesos participativos, además de promover el ejercicio de la ciudadanía y la gobernanza territorial, contribuyen a que la comunidad local tome el Plan como "su Plan".

Palabras clave: Plan; Participación; Gobernanza; Territorio; Políticas públicas. 


\section{INTRODUÇÃO}

A participação cidadã é uma das mais proeminentes formas de suporte $\mathrm{e}$ expressão da democracia. Os mecanismos participativos, são por essa razão, um instrumento ideal para manifestar e ativar os princípios emergentes e transformativos da democracia como instituição humana de governo.

Costuma-se associar a fundação das ideias democráticas modernas à pólis grega e à civitas romana. Existe, contudo, uma diferença entre ambas: A pólis é o lugar onde determinada gente, específica no que toca a tradições e costumes, tem a sua sede, na qual, por sua vez, tem o seu próprio éthos.

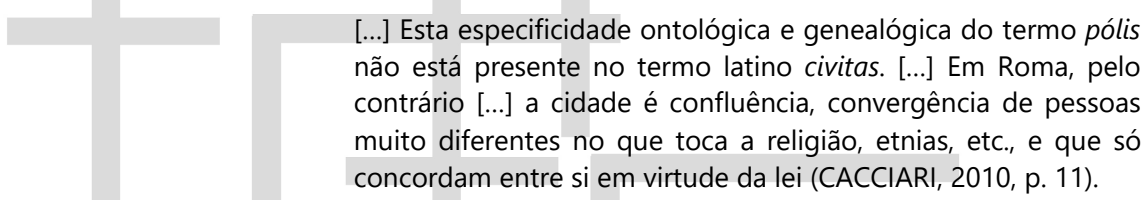

Essa segunda conceção está evidentemente mais próxima da ideia de cidade e política urbana europeia contemporânea. É nessa confluência e convergência de pessoas muito diferentes, que a participação pública adquire uma função crítica para o exercício da cidadania.

Sendo assim, a cidade - enquanto território histórico do espaço público onde essa configuração política foi inventada - é um dos fatores determinantes para as possibilidades de democracia. Porém, isso não implica em uma correlação direta entre a existência das cidades e o regime democrático (MOTTA, 2011). Sabe-se quão longe de se materializar está essa relação.

A auto-organização urbana - entendida como participação ou co-criação - sempre existiu e tem sido um componente fundamental da cidade. A auto-organização foi colocada dentro dos princípios evolutivos da sociedade pré-moderna, e muitas vezes configurou a forma comum de construção e evolução de uma cidade, onde as intervenções da autoridade e poder político se concentravam em alguns espaços e em algumas obras (CELLAMARE, 2018).

Contudo, essa ideia de auto-organização foi interrompida quando a sociedade moderna introduziu um novo modelo de planeamento urbano - nascido com a metropolização das cidades e a necessidade de gestão do regime do solo, a solução dos problemas saúde-sanitários das cidades em rápido crescimento, o repensar o espaço de acordo com a mobilidade e a eficiência, a procura de habitação - que passa a representar a forma de controle do espaço e governo das cidades.

Desde esse momento, a tomada de decisão sobre a gestão urbana, o regime jurídico e as políticas públicas, passou a ser delegada pela gestão das cidades, enquadrada no conceito de urbanismo stricto sensu (AMARAL, 1993). Entretanto, o planeamento dos aspetos que requerem um conhecimento exclusivamente técnico, mas na realidade sempre também políticos, vai ser responsabilidade de profissionais com habilitações específicas, que integram estruturas orgânicas fortemente hierarquizadas e burocratizadas. 
Outro fenómeno que caracterizou a metropolização das cidades era o impacto que produz sobre o espaço de cidadania, o que alterou as antigas coordenadas do espaço público. Houve, e ainda há, uma crescente "dessacralização" do meio ambiente e um crescimento de espaços privados sobre todos os outros, que obstruíam ou impossibilitavam o uso particular, e não para fins de consumo (MOTTA, 2011). Vivemos agora em um mundo no qual os direitos da propriedade privada e a taxa de lucro superam todas as outras noções de direitos (HARVEY, 2008), e em que "as leis do homem se substituíram àquelas que outros chamavam as leis da natureza, da geografia ou da história" (LAVEDAN, 1959, p. 49).

Apesar de tudo, as formas de participação pública e de auto-organização sobreviveram. Muitas vezes essas ações foram consideradas ilegais, e colocavam em xeque essa separação entre instituições e habitantes, como no caso dos assentamentos urbanos informais. Outras vezes, eram legalizadas, mas em condições de subalternidade face ao poder público, pugnando peloprecisando defender o direito de exercer a cidadania.

Essa nova sensibilidade política que se conscientiza sobretudo a partir dos anos 1960 do século XX - foi incorporada em diversos movimentos sociais e intelectuais, cujas críticas e busca de alternativas, ora radicais, estenderam-se, em prol do direito à cidade, a todas as dimensões sociais, como formas de propriedade, organização da economia, família, perspectiva de gênero, educação, trabalho, cultura, entre outras.

Nos últimos 20 anos, a natureza aberta e descentralizada da Internet, bem como a das tecnologias de informação e comunicação revelaram a sua capacidade para recriar manifestações concretas da prática e da experiência da democracia, além de explorar os seus significados em espaços mediatizados de engajamento cívico e interação política (GASTIL et al., 2020).

O surgimento dos meios digitais gerou toda uma série de expectativas em relação à reconfiguração da esfera pública, em resultado da emergência de uma sociedade em rede caraterizada por uma estrutura des-hierarquizada (CASTELLS, 2011) e por uma autonomia do poder "institucional" (CASTELLS, 2012). Por outro lado, salienta-se a perspetiva de os debates públicos serem mais inclusivos, especialmente dos segmentos da população mais marginalizados. Os meios digitais parecem ainda implicar a promessa de maior transparência, induzindo os decisores a serem mais responsivos e responsabilizáveis (De BLASIO, 2020). Neste mundo virtual navegam novos ideários como o da democracia digital, a e-governance ou o webativismo todos eles, tanto um meio com potencial para transformação deliberativa, como um meio para exploração antidemocrática.

\section{Enquadramento Teórico e Conceptual}

\section{A questão do Direito: perspetiva jurídico-instrumental}

O princípio da participação procedimental está consagrado no artigo $267 .^{\circ}$ da Constituição Portuguesa, sendo obrigação da Administração Pública "aproximar os serviços das populações e a assegurar a participação dos interessados na sua gestão efetiva", densificado no artigo $8^{\circ}$ do novo Código do Procedimento Administrativo, e 
nomeado no artigo $11 .^{\circ}$ - Princípio da colaboração com os particulares e no artigo $12 .^{\circ}$ - Princípio da participação.

O "Direito de participação procedimental e acção popular", é instituído pela Lei n. ${ }^{\circ}$ 83/95, de 31 de agosto (artigo $4^{\circ}, n^{\circ} 1$ ).

A adopção de planos de desenvolvimento das actividades da Administração Pública, de planos de urbanismo, de planos directores e de ordenamento do território e a decisão sobre a localização e a realização de obras públicas ou de outros investimentos públicos com impacte relevante no ambiente ou nas condições económicas e sociais e da vida em geral das populações ou agregados populacionais de certa área do território nacional devem ser precedidos, na fase de instrução dos respectivos procedimentos, da audição dos cidadãos interessados e das entidades defensoras dos interesses que possam vir a ser afectados por aqueles planos ou decisões. ${ }^{1}$

O novo Regime Jurídico dos Instrumentos de Gestão Territorial (RJIGT), publicado em 2015, estabelece o Direito à informação sobre a política de gestão do território e o Direito à participação na avaliação e execução dos programas e planos territoriais. No seu artigo $5 .^{\circ}$ refere-se o seguinte sobre o Direito à informação:

1 - Todos os interessados têm direito a ser informados sobre a política de gestão do território e, em especial, sobre a elaboração, a aprovação, o acompanhamento, a execução e a avaliação dos programas e planos territoriais.

No artigo 6. ${ }^{\circ}$ o decreto-lei, estabelece o Direito de participação nos seguintes termos:

1 - Todas as pessoas, singulares e coletivas, incluindo as associações representativas dos interesses ambientais, económicos, sociais e culturais, têm o direito de participar na elaboração, na alteração, na revisão, na execução e na avaliação dos programas e dos planos territoriais.

As entidades responsáveis pela elaboração e pelo depósito dos programas e planos territoriais devem criar e manter atualizado um sistema que assegure o exercício do direito à informação, fazendo uso de meios informáticos. Meios pelos quais devem, por sua vez, ser divulgados os tais programas e planos territoriais durante o processo de alteração, revisão, execução ou avaliação. Essa divulgação se dá através de "sítio" na Internet, na plataforma colaborativa de gestão erritorial (PCGT) e na comunicação social, facilitando, assim, a participação dos cidadãos.

Contudo, no mesmo artigo $6 .^{\circ}$, o legislador enquadra o verdadeiro compromisso da Administração Pública com o resultado do exercício do Direito de informação e de participação, confinando-o ao "dever de ponderação" e a uma "resposta fundamentada":

4 - As entidades referidas no número anterior estão sujeitas ao dever de ponderação das propostas apresentadas, bem como de resposta fundamentada aos pedidos de esclarecimento formulados, nos termos previstos no presente decreto-lei.

1 Artigo $4 .^{\circ},{ }^{\circ}{ }^{\circ} 1$. 
Dessa forma, entende-se que os responsáveis pelos programas e planos territoriais devem "ponderar" sobre as propostas apresentadas, sem compromisso com a sua implementação ou a sua integração às políticas públicas de ordenamento do território e urbanismo. Por sua vez, os pedidos de esclarecimento, aos quais deve ser dada uma "resposta fundamentada", geralmente relativos a aspectos técnicos, de direito de propriedade ou direitos adquiridos, ocasionalmente entrecruzados com questões de interesse público, mas, em sua grande maioria, concernem a interesses privados.

Sobressai, portanto, a ideia de que a participação pública se limita à audição dos indivíduos, grupos ou comunidades intervenientes, sem que haja efetiva obrigação de incorporar, nos programas e planos, as suas sugestões e propostas. Isto é, adotase uma estratégia de retórica que procura levar os cidadãos a acreditar que a sua opinião é considerada, sem excluir que, na verdade, cabe aos representantes responsáveis colocar o problema e, subsequentemente, a sua solução. Essa situação pode levantar algumas questões como: Estão em causa os princípios éticos que deveriam reger o processo de consulta pública? O regime jurídico está funcionando como um inibidor da participação cidadã? Essa prática recorrente da Administração Pública pode explicar, em parte, o enorme desinteresse dos cidadãos relativamente aos processos participativos?

De facto, é muito baixo o número de pessoas que acessam a plataforma PARTICIPA, ${ }^{2}$ onde são disponibilizados os processos sujeitos a consulta pública a cargo do Ministério do Ambiente e da Ação Climática. Acessando-a, é possível notar que são crescentes os níveis de abstenção eleitoral - nas eleições para a Assembleia da República em 2019, a taxa de abstenção era de 51\%, quando, em 1975, um ano após a revolução de abril de 1974 , a taxa registada era de $8,5 \%{ }^{3}$

Essas falhas do sistema democrático são transversais a vários países da União Europeia; por essa razão, nos programas comunitários, os compromissos com a igualdade passaram a ser introduzidos entre os principais desafios das políticas de coesão social e territorial, quase sempre associados a formas de governança territorial.

A governança territorial configura-se, atualmente, como uma das melhores estratégias para dar corpo social aos compromissos com a igualdade. Essa estrutura permite complementar, ou mesmo superar, alguns dos constrangimentos do planeamento tradicional, em especial no domínio dos planos municipais de ordenamento do território. No capítulo seguinte, analisa-se alguns dos conceitos e metodologias que orientam as políticas comunitárias da União Europeia.

\section{Governança territorial: estratégia comunitária europeia}

A política de coesão social e territorial da União Europeia, expressa na Nova Carta de Leipzig (2020), ${ }^{4}$ propõe que a transformação das cidades europeias e o seu desenvolvimento devem refletir a integração de três dimensões ou conceitos de

2 O portal disponível desde julho de 2015 permite pesquisar e acompanhar os processos e enviar contributos de participação. Disponível em: https://participa.pt/.

3 Fonte: PORDATA. Taxa de abstenção nas eleições para a Assembleia da República: total, residentes em Portugal e residentes no estrangeiro. Disponível em: https://www.pordata.pt/. Acesso em: 18 set. 2021.

4 B.2 Three Dimensions of European Cities, p. 3. 
cidade: a cidade justa, a cidade verde e a cidade produtiva. Porém, como se sublinha na Carta, essa "transformação integrada das cidades [...] só será bem-sucedida se atores governamentais e não governamentais de todos os níveis e setores trabalharem juntos, [...] com base numa compreensão compartilhada dos princípios fundamentais para a boa governança." Entre esses princípios, ${ }^{5}$ destacam-se o da participação e cocriação, a governança multi-nível e a abordagem de base-local.

A participação e cocriação, ou o co-design, correspondem a uma abordagem que requer o envolvimento do público em geral, cooperação com habitantes, redes da sociedade civil, organizações comunitárias e empresas privadas a fim de considerar as suas preocupações e conhecimentos. O recurso das metodologias de participação e cocriação tem indicado determinantes para a sustentabilidade dos processos de governança territorial.

No âmbito do planeamento regional e urbano, a governança territorial funciona como extensão do conceito mais estabelecido de governança multi-nível, por adicionar intuições explicitamente territoriais e, assim, focar-se numa abordagem de base-local e territorialmente mais sensível (ESPON, 2012). Numa abordagem de base-local, o território é um marco de referência para uma relação horizontal e vertical integrada. As estratégias territoriais e urbanas, bem como os seus instrumentos de planeamento e gestão, devem estar baseadas emuma análise sólida da situação local específica, focando nos potenciais benefícios e riscos, e acompanhando as lógicas do desenvolvimento e as idiossincrasias das comunidades locais. Isso permitirá uma transformação de base endógena e com tendência para reduzir as desigualdades socioeconómicas locais.

A governança territorial pode ser entendida como um modo organizacional de ação coletiva territorial, a partir da abertura e da transparência do processo em si, e na cooperação e coordenação, tanto horizontal quanto verticalmente, e em um quadro de subsidiariedade mais ou menos explícita (DAVOUDI et al., 2008).

Para o Programa Interreg Europe 2021-2027, especialmente focado no desenvolvimento das regiões de periferia, uma das prioridades políticas é a criação de "Uma Europa mais próxima dos cidadãos", proporcionando orientações estratégicas para o planeamento espacial e para o fortalecimento da dimensão territorial de todas as políticas relevantes em todos os níveis de governança:

Good territorial governance and cooperation are preconditions to counter current social, economic, connectivity and environmental challenges in the European territory. The diversity of the European territory in terms of geography, administrative and governance settings and political differences across regions emphasizes the importance of tailored, place-based approaches. [...].

No seu conjunto, estas estratégias colaborativas procuram capacitar as lideranças locais e regionais, e a qualificação do tecido institucional descentralizado e desconcentrado, através de plataformas de diálogo, de experimentação e implementação de políticas integradas e consonantes com as especificidades de cada territorialidade. Os planos municipais de ordenamento do território, por sua vez, são

\footnotetext{
5 C. Key Principles of Good Urban Governance, p. 5-7.
} 
excelentes instrumentos para a experimentação e implementação de estratégias participativas e de cocriação, bem como para a formulação de estratégias de baselocal; caso do projeto de revisão do Plano Diretor Municipal da Golegã que aqui se apresenta como tema de estudo.

\section{O Plano Diretor Municipal da Golegã}

\section{Sobre o lugar}

O município da Golegã pertence ao Distrito de Santarém, integrando, desde 2002, à região estatística (NUTS II) do Alentejo e na sub-região estatística (NUTS III) da Lezíria do Tejo, fazendo parte da Região de Lisboa e Vale do Tejo. A Golegã constitui, ainda, a Comunidade Intermunicipal da Lezíria do Tejo (CIMLT).

No Plano Regional de Ordenamento do Território - Oeste e Vale do Tejo ${ }^{6}$ - a Vila da Golegã é classificada como Centro Urbano Complementar, definido como espaços que prestam um leque de funções urbanas pouco diversificadas, mas fundamentais na sustentação da coesão territorial e na consolidação de redes de proximidade. Integram o sistema urbano municipal duas outras localidades - o Pombalinho e a Azinhaga, aldeia onde nasceu José Saramago, Prémio Nobel da Literatura em 1998.
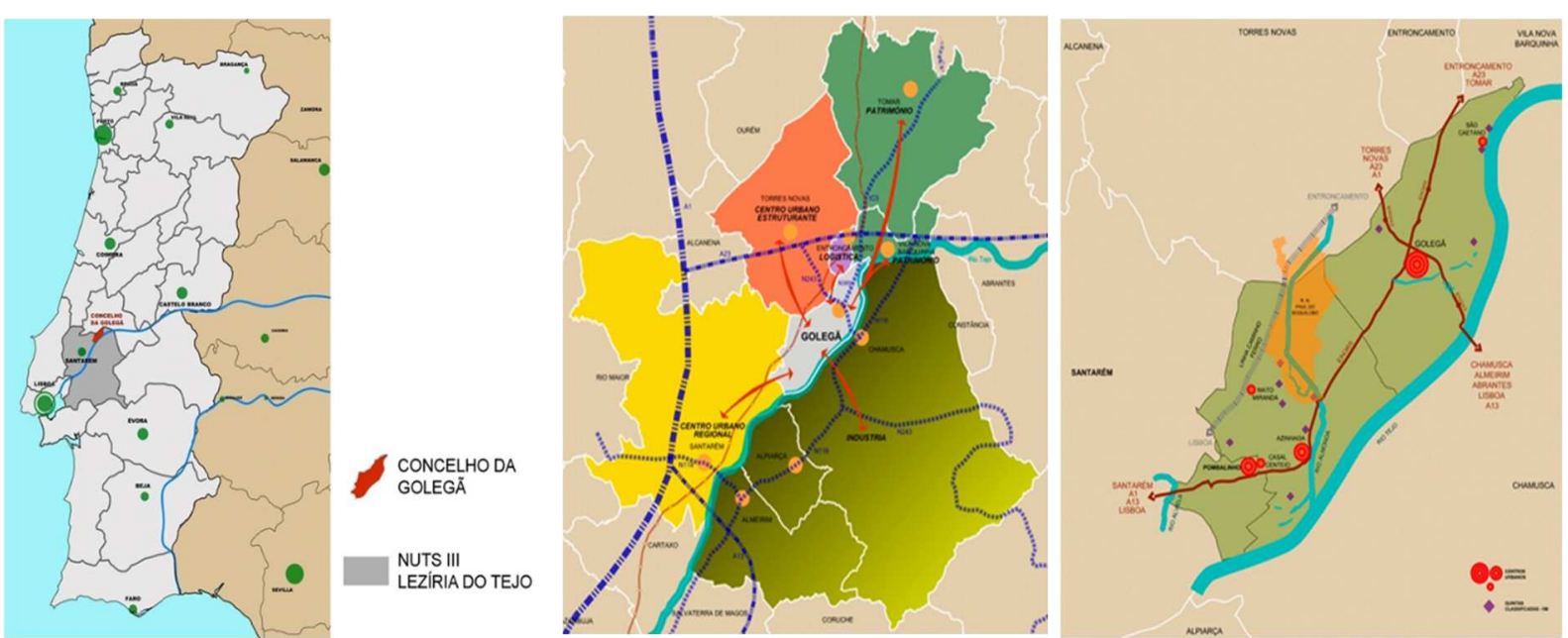

Figura 1: Município da Golegã: Enquadramento administrativo, enquadramento intermunicipal, sistema urbano. Fonte: Elaborada pelo autor (Relatório do PDMG).

Em consequência da reforma administrativa de 2013, o município passou a ter uma área total de 84,32 Km² e uma população de 5913 habitantes (CENSOS, 2011). Os resultados preliminares do Instituto Nacional de Estatística para 2021, indicam uma redução

6 No sistema de gestão territorial português, a elaboração dos Planos Regionais de Ordenamento do Território é uma competência das Comissões de Coordenação e Desenvolvimento Regional. 
populacional de $-8,7 \%$, sendo 5400 o número de habitantes atualmente a residir no concelho, o que corresponde a uma densidade populacional de $64,04 \mathrm{hab} . / \mathrm{Km}^{2}$.

A par da redução populacional, as dinâmicas sociodemográficas são caraterizadas por três transformações relevantes: i) o progressivo envelhecimento da população, carga que recai sobre a população ativa; ii) a tendência de decréscimo da população jovem, situação que se relaciona, sobretudo, com a influência dos saldos migratórios, dos baixos níveis de fecundidade e da conjugação de ambos; e iii) a diminuição da população em idade ativa, sendo que os dados estatísticos mostram que um número muito significativo de residentes na Golegã trabalha ou estuda noutro município.

O território do município da Golegã está indissociavelmente ligado à Lezíria do Tejo, uma unidade de paisagem agropecuária estruturada pela bacia hidrográfica do rio Tejo que, no troço final do seu percurso ibérico, se espraia para dar origem a uma vasta planície de terrenos férteis, os quais são explorados intensivamente há séculos.

A forma como, ao longo do tempo, as comunidades locais e regionais lidaram com o meio ambiente e cultivaram o solo conduziu à criação de uma paisagem singular. Esta utilização dos solos contribuiu para a definição da identidade desta região, a qual representa uma componente essencial do património cultural da Golegã.

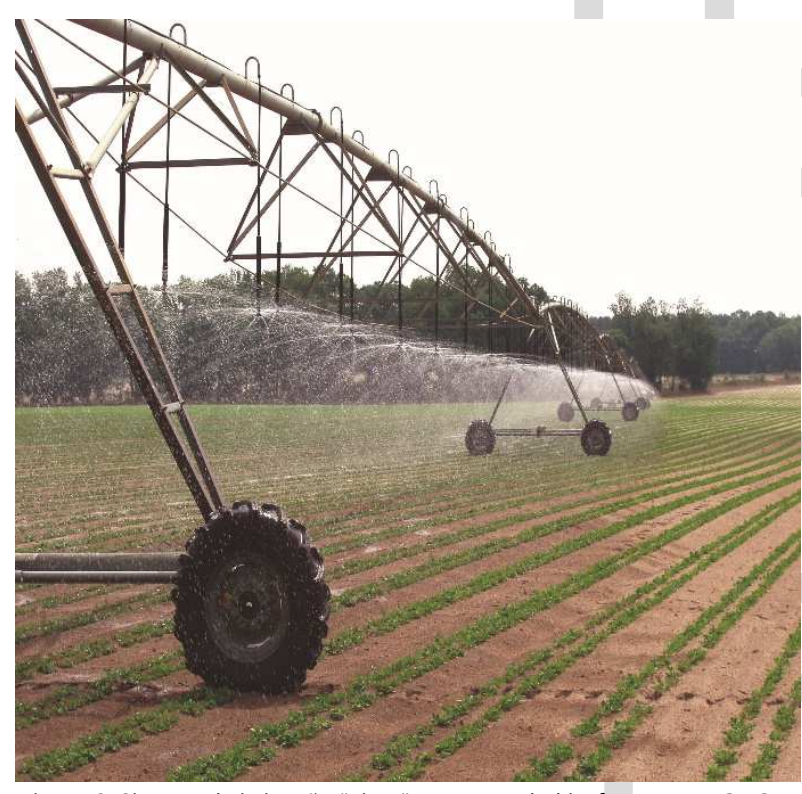

Figura 2: Sistema de irrigação "pivot" e Reserva da biosfera. Fonte: CMG.

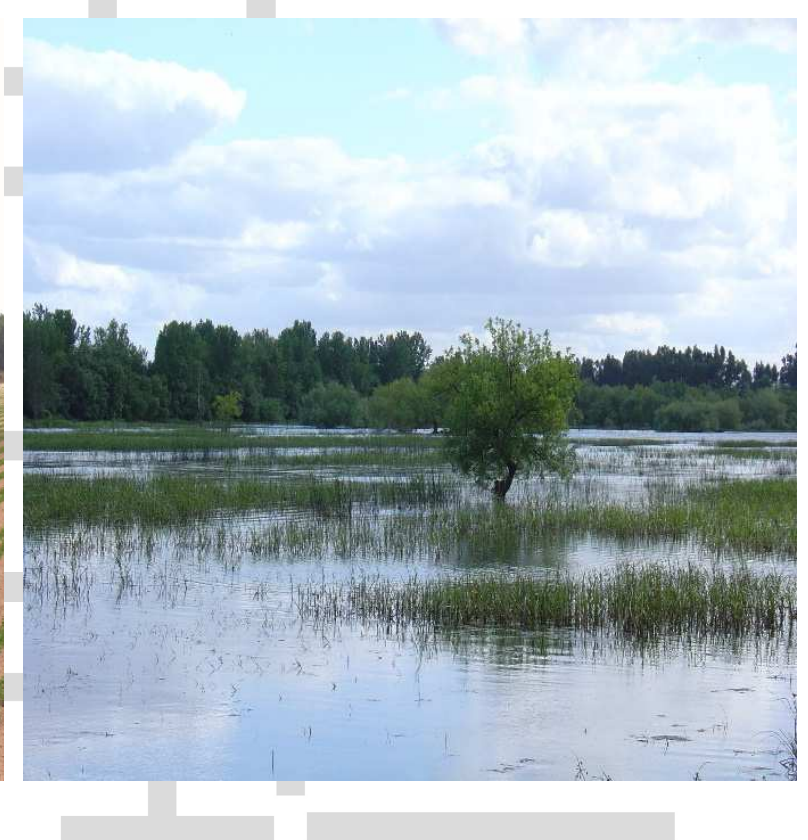

Integradas nesta passagem e associadas ao "mundo rural" devem ser assinaladas as práticas e a tradição secular radicada na cultura local da criação do cavalo lusitano. Essa referência chave do património imaterial da Golegã, conjuga a atividade equestre com as festas e feiras anuais, com projeção internacional, como a Feira Nacional do Cavalo, que coincide com a Romaria de São Martinho.

Falamos de um território com fortes raízes rurais onde a agricultura ainda tem um peso significativo, o que se traduz fortemente na tipologia das atividades econômicas e do 
seu tecido social. Igualmente apoiado em indústrias ligadas à exploração agrícola e ao setor terciário, o desenvolvimento da Golegã tem evoluído com base no que Philipe Saint-Marc (1996) denomina de "economia branda", um conceito e um modelo de desenvolvimento que hoje permite à Golegã dar um salto qualitativo e prosseguir a sua desenvolução, ancorada em novos domínios de planejamento econômico e de turismo sustentável.

Muito embora as suas localidades não sejam caraterizadas por morfologias e ambientes urbanísticos de conceituada menção, o concelho possui alguns edifícios de grande qualidade estética e destacado significado histórico, no quadro da arquitetura portuguesa. Por um lado, assinalam-se fortes testemunhos da plena Idade Modernacompreendia entre os séculos XV e XVIII -, que se explicam pela relação geo-concelhia de proximidade a Lisboa e à Corte; por outro lado, há edifícios de referência para a arquitetura dos séculos XIX e XX.

Sem preocupação de sistematizar, refiram-se alguns desses exemplos como: a Igreja Matriz, obra manuelina de Boitaca, classificada monumento nacional; as várias casas senhoriais, da qual se destaca a Quinta da Cardiga; o edifício Seiscentista que integra construções associadas aos Templários e à Ordem de Cristo; e a Casa-Estúdio de Carlos Relvas, recuperada há pouco anos para a sua função como habitação e atelier de fotografia, representa bem o ideário formal português dos finais de Oitocentos e inícios do século $\mathrm{XX}$, entre o Romantismo e as primeiras procuras de modernidade: constitui, um claro e original modelo de residência - "chalet", envolvida por jardim privado, evocativo de uma poética campesina e rural, mas o extremo cuidado da sua realização formal, a sua especial adaptação técnica e artística à função em causa fazem do conjunto obra única e exemplar em Portugal.
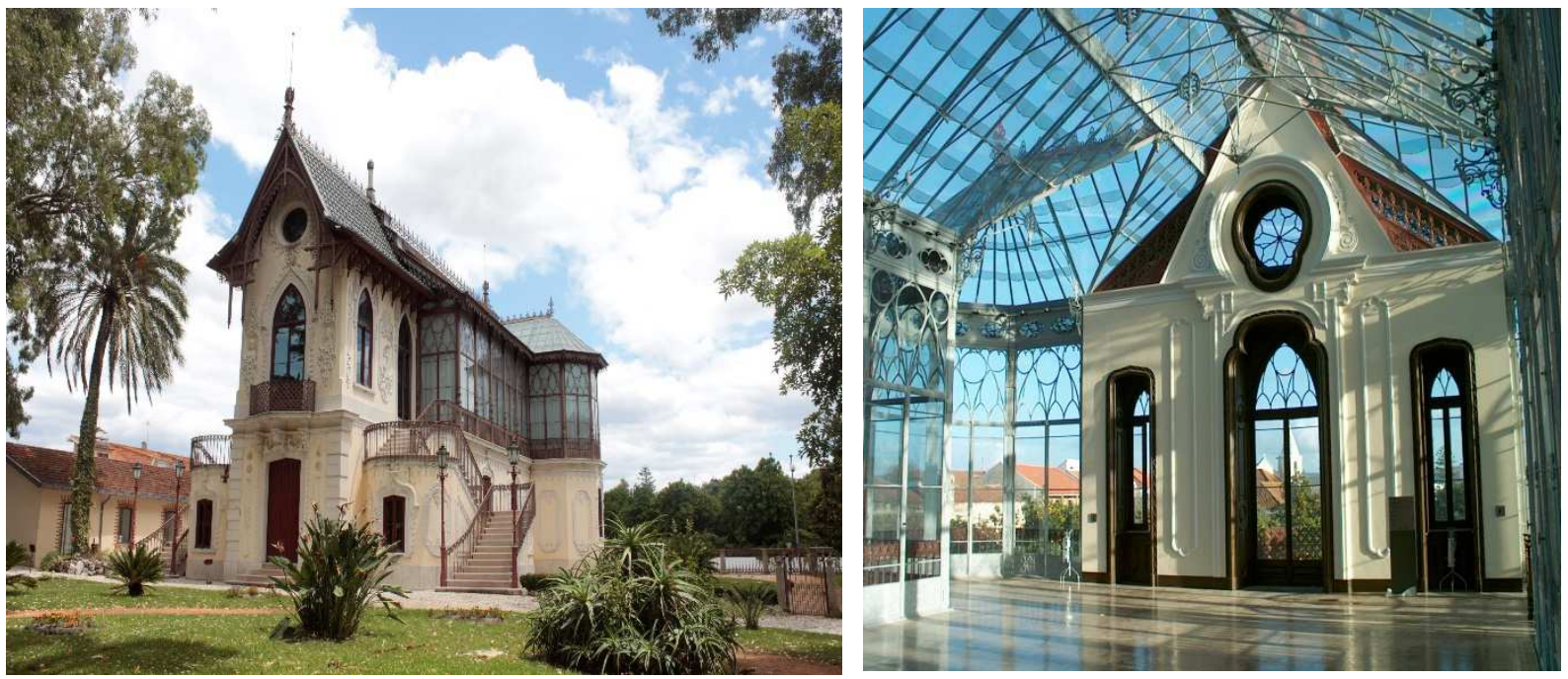

Figura 3: Casa Estúdio Carlos Relvas. Fonte: CMG. 
A elaboração do Plano Diretor Municipal da Golegã (PDMG) ${ }^{7}$ teve início em 2013, sendo apresentada a proposta de Plano de Ordenamento em abril de 2021. O Plano foi desenvolvido por uma equipe multidisciplinar, com a colaboração próxima dos técnicos da Câmara Municipal e uma cuidada atenção dos responsáveis autárquicos.

Uma das primeiras ações desenvolvidas, ainda antes de iniciar os trabalhos de caraterização e diagnóstico, foi a da realização de um conjunto de sessões públicas, no contexto de um processo participativo baseado na Metodologia Q (STEPHENSON, 1953), cuja operacionalização e resultados serão apresentados nos capítulos seguintes.

Com esse mecanismo de participação pública, a equipe técnica pôde adquirir um conhecimento mais profundo das principais dinâmicas socioeconómicas e culturais que caraterizam a população que vive e trabalha no município, ou que com ele mantém relações institucionais ou de negócio. Simultaneamente, a equipe registrou as perspectivas de desenvolvimento da comunidade local relativamente ao território municipal.

\section{A Metodologia Q}

A Metodologia Q foi desenvolvida por William Stephenson na década de 1930, a qual corresponde a uma investigação sobre o significado da consciência, da subjetividade, do próprio indivíduo, chegando enfim, ao significado fundamental da proliferação autorreferencial, publicada em The Study of Behavior: Q-technique and Its Methodology (1953).

Uma das formas de se utilizar o Método Q para estudos ambientais, em especial, para o ambiente construído refere-se à indicação de diferentes perspectivas sociais que existem sobre um assunto ou tema.

O Método Q combina as capacidades de pesquisa qualitativa e quantitativa tradicional (BROWN, 1996), utilizando dados que não podem ser medidos de maneiras convencionais, como sentimentos, opiniões ou soluções de uma pessoa, e dados que podem ser medidos e relatados em termos numéricos (AMIN, 2000). Embora esse método possa quantificar e simplificar valores, a sua vantagem é a possibilidade de captar a percepção dos entrevistados sobre qualquer tema (GIL; GUIMARÃES, 2011). O Método $\mathrm{Q}$ tem sido aplicado por diversos autores a fim de identificar perspectivas sobre questões de cidadania, interesse público, qualidade dos processos participativos, fatores motivadores na tomada de decisões sobre a utilização dos recursos e políticas ambientais (WEBLER et al., 2001), bem como em questões de desenvolvimento sustentável e sustentabilidade (CURRY et al., 2012).

O método tem vários passos-chave: a) formulação do concourse; b) seleção da amostra Q e testemunhos Q; c) ordenamento da pirâmide, Q sort; e d) análise e apresentação dos resultados. A seguir serão descritos, genericamente, cada um desses passos-chave.

7 A coordenação do projeto de revisão do Plano Diretor Municipal da Golegã é da responsabilidade da firma Carlos Almeida Marques, Arquitectura e Urbanismo Lda. O trabalho de análise e tratamento de dados obtidos da Metodologia Q foram realizados por investigadores da Associação para a Ciência e o Desenvolvimento dos Açores e da Universidade dos Açores. 
Formulação do concourse - Um estudo Q começa pela identificação de um domínio sobre um tema específico e um grupo de pessoas, e um segmento da sociedade, cujas perspectivas estamos interessados em conhecer. A relação entre o domínio de estudo e o grupo de pessoas configura o denominado concourse. A escolha do domínio ou tema de investigação deve ser fundamentado por um corpo de literatura, procurando agrupar, em texto, a informação disponível e o pensamento capaz de o representar. Por vezes, o texto é criado a partir de entrevistas com pessoas bem-informadas ou com conhecimento empírico sobre o objeto de estudo (WEBLER et al., 2009). Esta segunda opção foi adotada para o caso do Plano Diretor Municipal da Golegã, apresentado mais adiante.

Muitas vezes, a entrevista é uma forma eficiente e prática de recriar o concourse, pois pode-se garantir que todos os aspectos relevantes do tema sejam explicitamente discutidos e nada seja sistematicamente eliminado. Um dos benefícios da construção de um concourse a partir de entrevistas é que os testemunhos $\mathrm{Q}$ acabam vindo diretamente das pessoas que estão sendo estudadas. Consequentemente, a influência do pesquisador na concepção dos estímulos é minimizada ao ato de seleção de declarações (WEBLER; DANIELSON; TULER, 2009).

Seleção da amostra $Q$ e testemunhos $Q$ - A partir do concourse um conjunto de participantes é estrategicamente selecionado, ou seha, a amostra $Q(Q$ sample), que formularão o seu testemunho $Q(Q$ statement). Por sua vez, cada testemunho $Q$ é a expressão de um ponto de vista individual. Os participantes são pessoas com opiniões claramente diferentes, e são solicitados a expressar os testemunhos Q. Estes são classificados, formando assim uma coleçãode testemunhos, o denominado $Q$ sort (WEBLER; DANIELSON; TULER, 2009). Os testemunhos $Q$ devem ser concisos, mas formulados de modo que, na fase seguinte, os entrevistados possam mostrar o seu acordo ou desacordo com a ideia apresentada, e nunca devem conter conceitos contraditórios (AMIN, 2000).

Ordenamento da pirâmide, $Q$ sort - Cada testemunho $Q$ é impresso em pequenos cartões, o conjunto destes ( $Q$ sort) é apresentado de modo aleatório aos respondentes $\mathrm{Q}$ - que integram também a amostra $\mathrm{Q}$ - a quem é pedido que os avaliem de acordo com a importância que lhe atribuem, utilizando um esquema piramidal. A pirâmide é desenhada de modo a acomodar uma simples questão nos extremos (Figura 1). À esquerda (posição -4), os respondentes colocam a frase que, de acordo com o seu ponto de vista, menos representa o objeto-tema, e, à direita, (posição +4) colocam a frase que pensam melhor representar o objeto-tema.

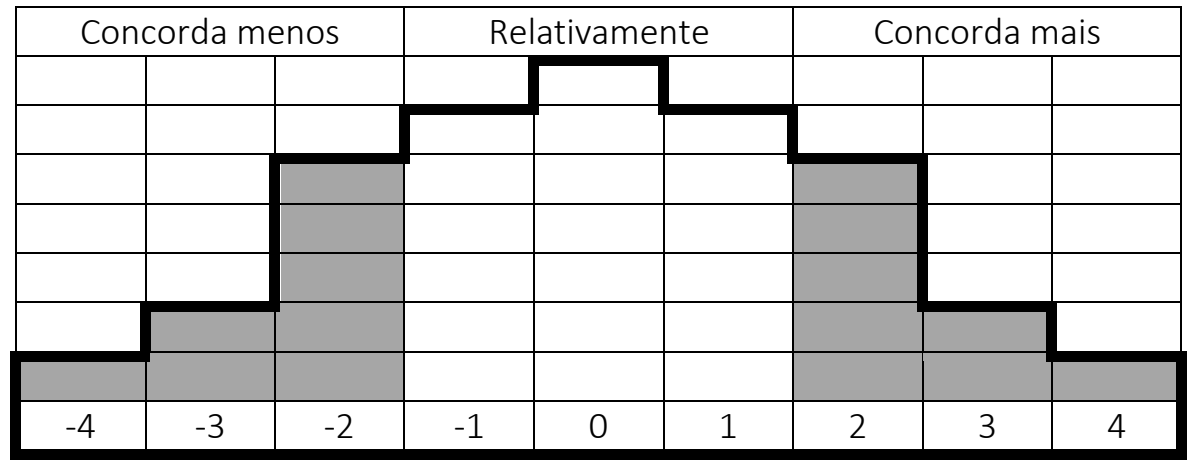

Figura 4: Q sort - esquema piramidal. Fonte: Relatório do PDMG (2013). 
À imagem dos entrevistados $Q$, também os respondentes $Q$ são selecionados para serem representativos de uma população, ainda que com designações distintas. Os respondentes $Q$ são selecionados para representar a amplitude de opinião em uma população-alvo, não a distribuição de crenças em toda a população. Também são escolhidos por terem opiniões razoáveis e diferentes, adequadamente e formadas. Pessoas que têm opiniões fundamentadas e coerentes acharão mais fácil participar no $\mathrm{Q}$ sort, e provavelmente produzirão um resultado mais robusto.

Normalmente, são coletados dos participantes/respondentes algumas dezenas de $\mathrm{Q}$ sort. Estas são analisados utilizando técnicas estatísticas de correlação e análise de fatores para revelar padrões na forma como as pessoas associam opiniões. ${ }^{8}$ Os resultados da análise são interpretados e expressos na forma de diferentes perspectivas sociais. Um estudo Q revela também como os indivíduos que participaram no $Q$ sort concordam ou discordam dessas perspectivas (WEBLER; DANIELSON; TULER, 2009).

Análise e apresentação dos resultados - $O$ método $Q$ é um tipo de pesquisa que integra técnicas qualitativas e quantitativas para revelar perspectivas sociais. Em um estudo $Q$, as variáveis são os $\mathrm{Q}$ sorts, pelos quais, como exprimimos anteriormente são perspectivas individuais, se dão as soluções de análise dos fatores que refletem princípios mais profundos de organização, sendo, por isso, chamadas de narrativas sociais (STEPHENSON, 1965). Cada solução apresenta uma série de "fatores", isto é, "ponto de vistas" ou "perspectivas", que explicam a variação dos dados. Todo fator é descrito como um arranjo particular dos testemunhos $\mathrm{Q}$.

A análise dos fatores pode envolver um significativo número de avaliações ou decisões de ponderação que intervêm na forma como se dá a investigaçãodos fatores, por meio do que é, habitualmente, chamado de "rotação". Rodar o fator implica uma mudança do seu significado, mas pode também tornar o fator mais relevante ou significativo. Este processo pode ser realizado com uma rotação automatizada por computador chamada "varimax", capaz de produzir a solução-fator que maximiza a quantidade de variância explicada no menor número possível de fatores (WEBLER; DANIELSON; TULER, 2009).

Contudo, o que determina se a solução alcançada é ideal, boa, aceitável ou pobre não depende de uma resposta matemática ideal. Embora haja orientação estatística, o investigador precisa possuir familiaridade como o objeto de estudo afim de fundamentar uma avaliação convincente dos resultados obtidos.

\section{Aplicação da Metodologia Q - valores e atitudes dos atores e agentes locais}

Num primeiro momento do projeto de revisão do Plano Diretor Municipal da Golegã, foi decidido realizar reuniões com um conjunto de agentes e atores locais nas áreas da ação social, da atividade económica, industrial, agrícola, turística e cultural, e também da administração do território. O objetivo dessa consulta pública era o de induzir uma

8 Existem vários programas infomáticos para análise dos dados recolhidos com recurso ao Principal Component Analysis (PCA), com rotação de factor "varimax", como o programa PQMethod v. 2.11. Outras versões de Q analysis software estão disponíveis em: http://pcqsoft.com/. Existem também vários programas informáticos que permitem analisar o Q sorting on-line, os quais se encontram listados na página de recursos do site qmethod.org: http://qmethod.org/links.php\#online. 
prática de democracia participada, através da qual fosse possível obter ex-ante informação dos atores e agentes locais sobre as potencialidades, ameaças, oportunidades e debilidades do concelho, a considerar na fase subsequente de elaboração da proposta de revisão do Plano.

A informação recolhida foi tratada com base na utilização da Metodologia $Q$, o que implicou seguir os seus passos-chave, começando pela formulação do concourse com a definição de um domínio de estudo. Neste caso, foi com o PDMG e a escolha do grupo de participantes $Q(Q$ sample) que se deu a formulação do testemunho $Q(Q$ statement). Como exposto anteriormente, o método passa pela escuta de testemunhos, por meio das quais percebe-se que as atitudes que esses testemunhos induzem, para, por fim estimular reflexões para ligar esses valores e atitudes ao diagnóstico dos problemas e à definição da estratégia de desenvolvimento do Concelho, com algumas questões-chave como:

Quais são as potencialidades, fraquezas, oportunidades e ameaças do desenvolvimento da Golegã? Qual a atitude dos agentes face a estas capacidades e limitações externas e internas? Qual a estratégia de desenvolvimento do Município tendo em atenção os valores e atitudes dos seus agentes e as capacidades e limitações internas e externas?

Essas foram as questões de abertura, mais vastas, colocadas aos entrevistados Q, cuja resposta deveria contribuir para a formulação dos testemunhos Q, os quais permitiriam perceber as motivações e os interesses dos principais atores e agentes ligados ao desenvolvimento do município. Com a Tabela 1, é possível rastrear várias sessões participativas, organizadas por áreas de atuação ou de atividade. 
Tabela 1. PDMG | ATORES E AGENTES LOCAIS - Q sample

\begin{tabular}{|c|c|}
\hline SAÚDE/AÇÃO SOCIAL & $\begin{array}{l}\text { ACES Lezíria } \\
\text { Sta. Casa Misericórdia Golegã } \\
\text { Sta. Casa Misericórdia Azinhaga } \\
\text { Casa Povo do Pombalinho } \\
\text { Administração Regional de Saúde de Lisboa e Vale do Tejo -ARSLVT-USG } \\
\text { Centro Social Paroquial Golegã } \\
\text { Conferências São Vicente de Paulo }\end{array}$ \\
\hline EDUCAÇÃO/DESPORTO & $\begin{array}{l}\text { Centro de Estudos Politécnicos da Golegã - CESPOGA/IPT } \\
\text { Agrupamento Escolas - GAP } \\
\text { Ginásios da Educação da Vinci } \\
\text { Escola Superior de Desporto de Rio Maior - ESDRM } \\
\text { Desporto Daniel Filipe } \\
\text { Futebol Clube Goleganense } \\
\text { Clube de Ténis da Golegã } \\
\text { Núcleo Sportinguista do Concelho da Golegã } \\
\text { Azinhaga Atlético Clube } \\
\text { Casa do Benfica na Golegã } \\
\text { Clube Desportivo em Movimento }\end{array}$ \\
\hline TURISMO/CULTURA & $\begin{array}{l}\text { Associação Nacional Turismo Equestre - ANTE } \\
\text { Lusitanus - Turismo Equestre SA } \\
\text { Divisão Intervenção Social (CMG) } \\
\text { Feira Nacional do Cavalo - FNC } \\
\text { Turismo do Alentejo e Ribatejo - ERT } \\
\text { Capriola (Restauração) } \\
\text { O Barrigas (Restauração) } \\
\text { Lusitanus (Restauração) } \\
\text { Central (Restauração) } \\
\text { Hotel Lusitano (Alojamento) } \\
\text { Quinta dos Álamos (Alojamento) } \\
\text { Casa da Azinhaga (Alojamento) } \\
\text { Casa da Tia Guida (Alojamento) } \\
\text { Pátio das Vendas (Alojamento) } \\
\text { Pátio da Avó Faustina (Alojamento) } \\
\text { Casa do Largo (Alojamento) } \\
\text { Quartos do Lagar (Alojamento) } \\
\text { Lusitanus S.A (Alojamento) } \\
\text { Solar do Espírito Santo (Alojamento) } \\
\text { Casa São Caetano (Alojamento) }\end{array}$ \\
\hline $\begin{array}{l}\text { AGRICULTURA/INDÚSTRIA } \\
\text { AGROALIMENTAR }\end{array}$ & $\begin{array}{l}\text { União Agrícola do Norte do vale do Tejo - AGROTEJO } \\
\text { Agromais - Entreposto Comercial Agrícola CDL } \\
\text { Direção Regional de Agricultura e Pescas de Lisboa e Vale do Tejo - DRAP LVT } \\
\text { Junta de Agricultores do Vale do Rio Almonda - JRAVA } \\
\text { Reserva Natural do Paúl Boquilobo -RNPB } \\
\text { Associação Empresarial Torres Novas, Entroncamento, Alcanena e Golegã - ACIS } \\
\text { Associação Empresarial da Região de Santarém - NERSANT }\end{array}$ \\
\hline ADMINISTRAÇÃO DO TERRITÓRIO & $\begin{array}{l}\text { Junta de Freguesia da Golegã } \\
\text { Junta de Freguesia da Azinhaga } \\
\text { Junta de Freguesia do Pombalinho }\end{array}$ \\
\hline
\end{tabular}

Tabela 1. PDMG | ATORES E AGENTES LOCAIS - Q sample. Fonte: Elaborada pelo autor (2021).

A Tabela 2 contém 31 frases que resumem os testemunhos dos atores e agentes entrevistados $Q$, cujos depoimentos foram registados pela equipa do plano. Essas frases foram, então, apresentadas aos respondentes $Q$ - não necessariamente coincidentes com os participantes anteriores -, pedindo que hierarquizassem as frases de acordo com o grau de concordância, seguindo o esquema piramidal da Figura 4, que corresponde ao $Q$ sort. 
Tabela 2. PDMG | Frases de testemunhos Q - Atores e Agentes de Desenvolvimento Local

1 O Plano Diretor Municipal não permite construir provocando a verticalização e a deslocalização dos jovens que ficam longe

dos seus familiares dificultando o apoio aos mais idosos.

2 É preciso ter cuidado com as novas áreas de expansão urbana quando temos área nas zonas urbanas que podem ser utilizadas.

3 Os edifícios das fábricas abandonadas devem ser utilizados para outros usos ou continuarão a ficar degradados e abandonados.

4 Temos que repensar a forma de prestar serviços de saúde concentrando os serviços e facilitando o transporte dos utentes e o serviço ao domicílio

5 As pessoas têm dificuldade em encontrar os serviços de saúde que necessitam

6 A Golegã está a ficar um município de gente idosa e com equipamentos e infraestruturas que não facilitam a acessibilidade às pessoas idosas.

7 Os idosos sofrem de uma solidão crescente e têm um grande medo de assaltos também porque as habitações são muito grandes e muito dispersas no tecido urbano porque há muitas casas desabitadas.

8 As pessoas não têm em que trabalhar na Golegã e os jovens não têm muitas possibilidades de criar o seu próprio emprego.

9 A base económica do Município da Golegã é a agricultura muito ligada à produção de milho que apresenta uma das mais altas produtividades da Europa.

10 As potencialidades da Golegã em Turismo são elevadas: temos os Caminhos de Santiago, temos o Paul do Boquilobo, temos até a visitação às áreas inundadas.

11 O município da Golegã tem equipamentos e infraestruturas dispersos que precisam ser vivificados com um planeamento e gestão integrada do desporto apoiado num observatório do desporto.

12 O município da Golegã deve promover a cooperação com as instituições de ensino superior do Ribatejo nomeadamente os Institutos Politécnicos de Santarém (com Escola de desporto de Rio Maior) e de Tomar

13 O município da Golegã, sendo um concelho plano, deve apostar no transporte de bicicleta designadamente complementando o desporto e o turismo.

14 É fundamental apostar na internacionalização das atividades económicas, sejam elas ligadas ao "cavalo", à agricultura ou à educação e ao desporto.

15 A marca da Golegã é a Feira do Cavalo, vêm visitantes de todo o mundo. É a maior feira do Ribatejo. É preciso um picadeiro coberto para provas indoor e a aposta no desenvolvimento do Centro de alto rendimento.

16 A Feira da Golegã traz à vila um turismo jovem noturno que tem um impacto negativo no turismo associado ao cavalo.

17 É fundamental apostar na utilização do recurso rio Tejo, na promoção do turismo e no desporto, tomando como exemplo e adaptando a aposta feita no rio Douro.

18 O caminho-de-ferro constitui fundamentalmente uma barreira. É importante reativar o apeadeiro de Mato Miranda, criando dimensão de tráfego que o justifique.

19 É preciso passar da potencialidade dos recursos (cavalo, agricultura, localização, cultura e o Tejo) à venda de produtos e serviços.

20 A Feira da Golegã estimulou a compra de habitações na vila por não residentes, desertificando-a quase todo o ano e criando sérios problemas ao comércio e aos serviços.

21 É fundamental criar parcerias entre os operadores turísticos para responder a procuras específicas de maior escala; alojar grupos em várias hospedarias, mobilizar cavalos ou bicicletas para grupos maiores.

22 É muito importante melhorar o acesso da Golegã ao IC3 com uma nova travessia do rio Tejo mais larga que a atual e uma alternativa viária à estrada do dique dos vinte.

23 A ocupação do solo na Golegã é muito condicionada pelo meio ambiente - zona inundável - e por regulação muito restritiva ao uso eficiente do solo - reserva do Paul do Boquilobo, RAN e REN.

24 O ordenamento do município da Golegã deveria permitir a criação de assentos de lavoura fora da zona urbana, pois esta não permite com facilidade a movimentação de máquinas e equipamentos atuais.

25 O projeto de emparcelamento agrícola da Golegã deve ser terminado, sendo necessário a transferência de verba pública para completar o projeto.

26 Deveríamos atrair as agroindústrias para junto dos agregados do município da Golegã para promover o emprego ligado às competitivas cadeias de valor da agricultura

27 O Paul do Boquilobo deve ser gerido com uma parceria entre o município e o Instituto de Conservação Natureza e Floresta de forma a compatibilizar os interesses dos agricultores, dos turistas e da conservação.

28 O Plano Diretor Municipal deve ser um instrumento não só de integração de legislação, mas de promoção da sua adequação do desenvolvimento sustentável do município.

29 O município da Golegã deveria valorizar a memória dos que ganharam fama fora do município: o escritor José Saramago, o fotógrafo Carlos Relvas, etc.

30 A Golegã deve apostar na centralidade das suas empresas agroindustriais que juntam valor pela transformação e comercialização de produtos agrícolas do Alentejo e Ribatejo.

31 A Golegã deve apostar nas grandes potencialidades que tem no campo da restauração, aproveitando a centralidade rodoviária que pode ganhar com melhores acessos e sinalização aos eixos viários nacionais.

Tabela 2. PDMG | Frases de testemunhos Q - Atores e Agentes de Desenvolvimento Local. Fonte: Relatório do PDMG (2013). 
O tratamento dos dados recolhidos foi realizado através do método de Análise dos Componentes Principais (PCA), com aplicação de fator de rotação "varimax" $(P Q M e t h o d)$. A interpretação foi feita para cada fator, e em comparação com os demais fatores, para definir os pontos de concordância e discordância. O PCA permitiu identificar nove componentes - grupos ou perspetivas sociais - que sintetizam os depoimentos dos 30 respondentes $Q$, expressos de modo hierarquizado com base no esquema piramidal. De acordo com a metodologia aplicada, foram identificados os componentes mais representativos da variedade de interesses do município, estando estes associados a alguns dos agentes de desenvolvimento que a outros.

$1^{\circ}$ Componente: Aposta nas potencialidades do capital natural - com ele, privilegia-se as potencialidades do concelho na agricultura e na agroindústria, no desejo do ordenamento e das políticas públicas que promovam a sustentabilidade da vocação da terra fortemente marcada pelo Rio Tejo. Este primeiro componente, valoriza o capital dos recursos naturais da Golegã, e é marcadamente urbano e diversificado, sendo ele expresso pelos: comerciante, funcionário da Câmara Municipal, gestores do restaurante e do turismo, pela junta de freguesia da Azinhaga, entre outros. É razoável que assim seja, uma vez que as potencialidades naturais dos sítios são assumidas por todos, mesmo por aqueles que não têm diretamente afinidade com a gestão desses recursos comuns.

$2^{\circ}$ Componente: Aposta nas potencialidades do capital cultural e humano - o qual manifesta a preocupação com a falta de emprego - em especial para os jovens; a explicitação da memória a José Saramago, Carlos Relvas e outros, a Feira do Cavalo e a preocupação com o ordenamento dos equipamentos (de desporto) em função das pessoas. Esse posicionamento em favor do potencial humano e cultural é, de certa forma, coerente com a aposta na internacionalização da Golegã com base nos seus recursos humanos e culturais -associados à cultura de criação e comercialização de cavalos. Também tem interesses mais próximos, manifestados pelo estudante universitário, pela empresa de consultoria, pelo centro paroquial com responsabilidades na educação e pelos representantes dos empresários. Para todos estes, a educação e a assunção cultural da Golegã é fundamental para os seus interesses.

$3^{\circ}$ Componente: Restrições nas infraestruturas públicas que servem a Golegã - eeste tópico releva as restrições das infraestruturas públicas para o desenvolvimento do município, seja a preocupação com a ligação ao Itinerário Complementar (IC3), seja a necessidade de reativação da estação ferroviária de Mato Miranda. A primeira,que se clarifica quando se refere que a intervenção pública nas infraestruturas e no PDMG. deve promover a competitividade das cadeias de valor da Golegã. Este terceiro componente explicita as restrições criadas por infraestruturas e equipamentos em falta e, naturalmente, é manifestado pelo empresário da construção civil e por pessoas que vêm, em infraestruturas específicas. limitações relevantes ao desenvolvimento.

$4^{\circ}$ Componente: Potencialidades dos espaços urbanizados e preservação dos solos agrícolas - aqui, considera-se o uso de espaços urbanizáveis dentro da Vila ou a utilização de edifícios de fábricas abandonadas são sinais claros desta preocupação. Implicitamente pretende-se proteger a riqueza dos solos agrícolas da Golegã; isso é patente quando este posicionamento é contra a criação de assentos de lavoura nos espaços agrícolas, argumenta ainda que o PDMG não limita a fixação de pessoas e, ao contrário do defendido na $3^{\mathrm{a}}$ componente, não acha relevante a melhoria de ligação 
ao IC3, se tal implicar a destruição de solos (nossa interpretação). A quarta componente é protagonizada pela Direção Regional da Agricultura, pelo gestor da Feira do Cavalo, por um residente da Golegã e por um monitor de desporto. Vale pontuar, ainda, que os agentes que menos valorizam a proteção do solo são os residentes de Pombalinho, os quais veem nela uma restrição ao desenvolvimento.

$5^{\circ}$ Componente: Restrições na saúde, turismo, comercialização e desporto - com ele, argumenta-se que os serviços de saúde devem ser extensivos aos domicílios, e defende-se que o rio Tejo deve ser bem aproveitado para o desporto e para o turismo. Também sugere-se o estímulo no uso da bicicleta e a coordenação entre agentes para o aluguel de bicicletas e de cavalos pelos turistas, e aponta-se, por fim, que há problemas graves na comercialização de bens e serviços gerados na Golegã. Curiosamente essa postura não se revê nas potencialidades agrícolas e agroindustriais do município, não concorda que os jovens tenham dificuldade em criar emprego, e negligencia a ligação rodoviária ao IC3, que apresenta ser um estímulo ao atravessamento do município por tráfego pesado. O quinto componente também apontam problemas em grande parte associados à dificuldade em comercializar os produtos e serviços gerados na Golegã. Contudo, a Associação Empresarial e Comercial, a Delegação de Turismo e a Agrotejo não se adotam este posicionamento, que questiona a efetividade do desempenho das suas competências.

$6^{a}$ Componente: Falhas de governança - este grupo de atitudes tem o seu foco na necessidade de implementar um modelo de governança territorial que permita concluir o projeto de emparcelamento agrícola, no facto de o Paul do Boquilobo (Reserva Natural da Biosfera) não estar a ser gerido de modo a potenciar o desenvolvimento e sustentabilidade da área e ainda a falta de "ambiente político" que fomente as parcerias para criar escala nas atividades de apoio ao turismo e evitar que os equipamentos públicos estejam pouco adequados para o serviço à população idosa. Este componente tem pouca expressão entre a maioria dos participantes e, curiosamente, agrega os docentes de ensino superior não residentes no município, que responderam ao questionário.

$7^{\circ}$ Componente: Oportunidades endógenas - componente que parte de uma atitude de algum isolacionismo, explicitamente contra a vinda de jovens para "a noite" na Feira da Golegã e aposta em investimentos específicos, públicos e privados, mesmo pondo em causa alguma área do solo rico dos campos da Golegã. Não vê qualquer limitação nos instrumentos de regulação do território como o PDMG, embora solicite, em aspectos pontuais, a sua revisão como a criação de uma rede de serviços de saúde descentralizada, o estabelecimento de centros de lavoura fora dos núcleos urbanos e a ligação ao IC3.

$8^{\circ}$ Componente: Oportunidades exógenas - as respostas deste grupo têm que estar ligadas, fundamentalmente, com as oportunidades relacionadas ao turismo, ao reconhecimento externo e a explicitação da memória de personalidades históricas do concelho, e em concordância com o segundo componente, acrescentado outras oportunidades como os Caminhos de Santiago, a Reserva Natural do Paul de Boquilobo e o Rio Tejo. Este conjunto revela-se menos preocupado com as questões associadas ao serviço de saúde domiciliário, ao projeto de emparcelamento, à reativação da estação ferroviária de Mato Miranda ou ao uso parcimonioso do solo. 
$9^{\circ}$ Componente: Pombalinho, restrições de regulação do solo - o último componente distingue-se claramente das outras por conta de os respondentes $Q$ pertencerem à freguesia do Pombalinho. Mostra que o PDM em vigor e feito no âmbito do Município de Santarém restringe o enraizamento de jovens, o que leva ao envelhecimento da população da freguesia e ao isolamento dos mais idosos. É também clara a aposta no turismo. No mais, os respondentes parecem satisfeitos com os serviços de saúde existentes e não se identificam com o projeto de emparcelamento agrícola previsto para a Golegã.

\section{Resultados}

A opção por iniciar o projeto de revisão do Plano Diretor com um processo participativo, resultou de uma dupla abordagem metodológica: a formulação de uma proposta de planeamento físico conexa a um processo de planeamento estratégico.

Essa dupla abordagem foi considerada essencial para que fosse possível lidar com os desafios do desejado desenvolvimento harmonioso e sustentável. Entende-se o plano como instrumento de objetivos paralelos sendo eles, em matéria legal, regulamentar; possuir capacidade de responder de modo proativo à satisfação das necessidades infraestruturais, e uma prática que torna as políticas de território indissociáveis da realidade social e cultural das populações.

Por sua vez, o recurso a métodos de planeamento estratégico resultou da constatação das vantagens em adotar um processo de elaboração integrada e compreensiva, orientada para garantir uma estrutura negocial e de participação com a comunidade local. Comunidade representada pelos atores e agentes locais, isto é, os que participaram no processo de consulta pública.

A implementação de processos participativos ex-ante, a fim de, além de favorecer o exercício da cidadania e a governança territorial, contribuir para que a comunidade local assuma o Plano como "O seu Plano». Essa execução tamém fornece à equipe técnica e aos responsáveis autárquicos, elementos-chave para um ordenamento adequado do território, e elementos facilitadores e orientadores da concretização de ações propostas pelo PDMG.

Os conteúdos dos nove componentes, obtidas com recurso da Metodologia Q, deramse a partir da Proposta de Plano, refletindo-se no conjunto de objetivos gerais e específicos, que se resumem na Tabela 3 e 4 .

Esses objetivos irão configurar a proposta de modelo territorial e as opções de base para desenvolver prioridades e objetivos reais: melhoria da qualidade de vida das populações; ordenamento do uso e ocupação do solo; consolidação das atividades económicas existentes e do incentivo a outras atividades ligadas à exploração agrícola; desenvolvimento da cultura e do turismo cultural; incremento de linhas de comercialização resultantes da oferta de serviços e produtos locais, sendo todas esses propósitos naturalmente associados aos domínios de inovação tecnológica. 
Tabela 3. PDMG | OBJETIVOS GERAIS

\begin{tabular}{|c|c|}
\hline OBJETIVO & ORIENTAÇÕES PROGRAMÁTICAS E ESTRATÉGICAS \\
\hline 1. COMPETITIVIDADE & $\begin{array}{l}\text { Vocacionar a Golegã como centro de encontro social, lugar de lazer e } \\
\text { espaço de uma oferta de turismo cultural, no contexto sub-regional } \\
\text { formado por um sistema urbano policêntrico com Torres Novas, } \\
\text { Abrantes, Entroncamento, Santarém, Almeirim, Alpiarça e Chamusca, } \\
\text { predominantemente ligados às atividades industriais e terciárias. }\end{array}$ \\
\hline 2. QUALIDADE DO MEIO AMBIENTE & $\begin{array}{l}\text { A perceção da Paisagem como elemento fundamental a preservar, não } \\
\text { apenas de um ponto de vista histórico, estético ou pela biodiversidade } \\
\text { que abriga, mas porque constitui também um potencial económico de } \\
\text { grande valor. }\end{array}$ \\
\hline 3. COESÃO SOCIAL & $\begin{array}{l}\text { A necessidade de superar o problema da insustentabilidade resultante } \\
\text { das dinâmicas sociodemográficas do município, seja porque (a) existe } \\
\text { degradação do capital infraestrutural, produtivo, humano, cultural e } \\
\text { natural seja porque (b) se verificam limitações à sua utilização } \\
\text { sustentável pelo desempenho da economia, que se revela incapaz de } \\
\text { gerar emprego que assegure o enraizamento dos jovens e a transmissão } \\
\text { e recriação do legado cultural. }\end{array}$ \\
\hline 4. CRIAÇÃO DE REDES & $\begin{array}{l}\text { A partir de temáticas que tenham potencialidades para ser desenvolvidas } \\
\text { em rede, com outras instituições, ações e/ou iniciativas, já existentes, na } \\
\text { mesma esfera geográfica, ou de interatividade nacional ou internacional. }\end{array}$ \\
\hline 5. INTERNACIONALIZAÇÃO & $\begin{array}{l}\text { Incentivar a internacionalização das ações ligadas as atividades culturais } \\
\text { com especial enfoque no Centro de Alto Rendimento, Feira Nacional do } \\
\text { Cavalo, Casa Estúdio Carlos Relvas. }\end{array}$ \\
\hline 6. IDENTIDADE LOCAL & $\begin{array}{l}\text { Modelo de desenvolvimento da identidade local a partir de escolhas } \\
\text { temáticas dentro da tradição e continuidade históricas e regionais, bem, } \\
\text { como da realidade cultural, social e económica concelhia. }\end{array}$ \\
\hline $\begin{array}{l}\text { 7. MODELOS COLABORATIVOS DE } \\
\text { GOVERNANÇA LOCAL }\end{array}$ & $\begin{array}{l}\text { A necessidade de implementar um modelo de governança territorial que } \\
\text { permita superar falhas no sistema de gestão do território que podem } \\
\text { estar na origem de bloqueamentos da ação dos agentes e atores do } \\
\text { desenvolvimento local. }\end{array}$ \\
\hline
\end{tabular}

Tabela 3. PDMG | OBJETIVOS GERAIS. Fonte: Elaborada pelo autor (2021).

Os objetivos gerais, descritos na Tabela 3, podem ser lidos como reflexo de orientações programáticas e estratégias para enquadrar o desenvolvimento local nas agendas mais globais e multi-escalares. Na Tabela 4, os objetivos específicos convergem sobre as ações e compromissos a adotar, face às realidades emergentes locais. As orientações estratégicas e programáticas centralizam-se nos temas do desenvolvimento municipal e da preservação e ativação do patrimônio cultural, natural e ambiental da Golegã, enquanto fatores-chave para a sustentabilidade do modelo de vida das suas comunidades. 
Tabela 4. PDMG | OBJETIVOS ESPECÍFICOS

\begin{tabular}{|c|c|}
\hline OBJETIVO & ORIENTAÇÕES PROGRAMÁTICAS E ESTRATÉGICAS \\
\hline \multirow[t]{2}{*}{$\begin{array}{l}\text { 1. CONSERVAÇÃO E } \\
\text { ATIVAÇÃO DO PATRIMÓNIO } \\
\text { NATURAL }\end{array}$} & $\begin{array}{l}\text { Os rios Tejo e Almonda constituem áreas de interesse ecológico exibindo valores naturais } \\
\text { relevantes. Não possuem, contudo, qualquer regime de proteção, sendo fundamental } \\
\text { assegurar a sua conservação e valorização ambiental. }\end{array}$ \\
\hline & $\begin{array}{l}\text { Devem ser mantidas as atividades agrícolas orientadas para a valorização sustentada dos } \\
\text { recursos naturais, paisagísticos e culturais. }\end{array}$ \\
\hline \multirow[t]{2}{*}{$\begin{array}{l}\text { 2. CONSERVAÇÃO E } \\
\text { ATIVAÇÃO DO PATRIMÓNIO } \\
\text { MATERIAL RURAL }\end{array}$} & $\begin{array}{l}\text { As edificações senhoriais integrantes de propriedades rurais ou quintas, representativas da } \\
\text { cultura rural goleganense, constituem um fator identitário a preservar e integrar no processo } \\
\text { de ordenamento do território municipal. }\end{array}$ \\
\hline & $\begin{array}{l}\text { A Quinta da Cardiga e vários espaços antigos industriais, atualmente desocupados, } \\
\text { constituem um valor patrimonial de excelência, cujo enorme potencial turístico carece de ser } \\
\text { explorado através da sua reconversão para novas funcionalidades. }\end{array}$ \\
\hline $\begin{array}{l}\text { 3. ATIVAÇÃO DO } \\
\text { PATRIMÓNIO CULTURAL } \\
\text { IMATERIAL E } \\
\text { PONTENCIALIDADES DOS } \\
\text { RECURSOS HUMANOS }\end{array}$ & $\begin{array}{l}\text { A Golegã tem potenciado um dos principais recursos do seu património cultural, o da criação } \\
\text { do cavalo. O Centro de Alto Rendimento (CAR) confere novas valências ligadas às disciplinas } \\
\text { do desporto equestre no domínio da Alta Competição e constitui uma das principais âncoras } \\
\text { para o desenvolvimento e valorização do seu potencial em recursos humanos endógenos } \\
\text { nesse domínio. }\end{array}$ \\
\hline \multirow[t]{2}{*}{$\begin{array}{l}\text { 4. TURISMO CULTURAL E DE } \\
\text { NATUREZA }\end{array}$} & $\begin{array}{l}\text { O Tejo pode coincidir com um novo Pólo económico, em torno do turismo fluvial, orientado } \\
\text { para a valorização dos recursos naturais, paisagísticos e culturais. }\end{array}$ \\
\hline & $\begin{array}{l}\text { A Golegã possui unidades de acolhimento de turismo de habitação, turismo rural e } \\
\text { agroturismo, que possuem, uma história muito rica sendo e elementos identitários de grande } \\
\text { relevância para o turismo cultural e de natureza. }\end{array}$ \\
\hline $\begin{array}{l}\text { 5. POTENCIALIDADES DOS } \\
\text { SETORES DA AGRICULTURA, } \\
\text { INDÚSTRIA E COMÉRCIO }\end{array}$ & $\begin{array}{l}\text { A atividade agrícola está afetada por vicissitudes estruturais que ameaçam a sua viabilidade e } \\
\text { sustentabilidade, tanto técnica como económica e ambiental. O Projeto de Emparcelamento } \\
\text { Rural pode minimizar parte destes problemas, procurando obter resultados que apoiem esta } \\
\text { importante atividade produtiva. }\end{array}$ \\
\hline
\end{tabular}

As zonas definidas para atividades industriais e logísticas, são suficientes face aos atuais níveis de investimento nas atividades produtivas agroalimentares ou outras, sendo os concelhos vizinhos fortemente concorrentes nesta matéria.

O comércio local apresenta diversas insuficiências: os espaços comerciais encontram-se envelhecidos e sem oferta atrativa de produtos, diversas lojas estão devolutas. Justifica-se a elaboração de um projeto de urbanismo comercial.
6. EQUIPAMENTOS PÚBLICOS Contata-se a boa localização dos Serviços de Saúde. Contudo, na consulta pública foi referido que o serviço funciona de modo desigual para o concelho, por insuficiência de recursos humanos para responder ao número crescente de solicitações. Os equipamentos de Saúde e Ação Social Educação e Desporto Infraestruturas Gerais Assistência Social existentes são também suficientes para as necessidades da população, justificando-se a criação na Azinhaga de um Lar ou Centro de Dia para acolhimento dos idosos.

Não se constata a necessidade de novos Equipamentos Escolares. A atual oferta de Equipamentos de Desporto é excessiva para as necessidades e faltam recursos humanos para a sua gestão e correto funcionamento.

Deve ser questionado o interesse na realização da ligação ao IC3.

\begin{tabular}{ll}
\hline 7. ORDENAMENTO DO & Para os aglomerados urbanos foram definidos parâmetros de ocupação densificada e uma \\
ESPAÇO & configuração de acordo com o modelo territorial baseado no conceito de CIDADE \\
Cidade Compacta & COMPACTA. \\
Reabilitação Urbana & $\begin{array}{l}\text { No concelho foram constituídas } 7 \text { Áreas de Reabilitação Urbana, que correspondem a } \\
\text { Adaptação às alterações }\end{array}$ \\
climáticas & essencialmente dirigida à reabilitação do edificado. \\
& Considera-se prioritário na proposta de plano atribuir à proteção do ambiente um papel \\
& essencial no processo desenvolvimento territorial, através do reordenamento do trânsito e \\
& criação de novas formas de mobilidade, da criação de espaços públicos qualificados e da \\
& valorização/proteção ambiental de linhas de água ou frentes ribeirinhas. Impõe-se a adoção \\
& de medidas sobre matéria de aproveitamento dos recursos energéticos, redução dos fatores \\
& de poluição da atmosfera, proteção dos solos e recursos hídricos.
\end{tabular}

Tabela 4. PDMG | OBJETIVOS ESPECÍ́FICOS. Fonte: Elaborada pelo autor (2021). 
Como se pode observar, em ambas as Tabelas 3 e 4, a formulação dos objetivos gerais como dos objetivos específicos, integram-se os valores e atitudes dos atores e agentes locais, expressos nos nove componentes ou perspectivas sociais identificadas a partir do $Q$ sort. Essas perspectivas sociais correspondem a opções alternativas de desenvolvimento, tendo sido possível, com a Metodologia Q adotada, caraterizar e ponderar quais delas teriam impactos favoráveis para alcançar os objetivos de coesão social e responder às políticas públicas locais de ordenamento territorial e urbanismo.

\section{NOTAS FINAIS}

As temáticas ligadas à participação cidadã têm sido, há um considerável período, campo de estudo e de análise propositiva no contexto do planeamento urbano como disciplina e investigação científica.

A Metodologia Q é exemplo disso, a par de diversos outros modelos e estratégias de participação como a advocacia urbana, os laboratórios de inovação ou os trusts comunitários, sendo possível descrevê-la em "a cidade que se planeia" na forma como cada um deles é aceito por toda comunidade, integrada ao seu corpo social próximo ou eventualmente conectados, de modo global, aos sistemas digitais participativos, como o da e-governance ou o webativismo.

No caso do projeto de revisão do PDMG, a escolha da Metodologia Q foi considerada a mais adequada pela sua capacidade de combinar a pesquisa qualitativa e a quantitativa tradicional, os dados poderem ser medidos e relatados em termos numéricos; e de captar a percepção dos entrevistados sobre questões de cidadania, interesse público e fatores motivadores na tomada de decisões em matéria de planeamento regional e urbano.

A Metodologia Q proporciona desenvolver o que pode-se denominar por inteligência estratégica, a qual visa fundamentar e melhorar a tomada de decisão, identificar as oportunidades, elencar as forças e as fraquezas do território de intervenção, e, por fim, prever e antecipar os fatores de mudança e as dinâmicas dos processos urbanos transformativos.

A partir do que foi exposto anteriormente, acredita-se ter sido mostrado que a participação cidadã suporta os meios fundamentais para o sucesso da governança territorial, confere capacidade ao governo municipal para implementar políticas sólidas de desenvolvimento sustentável, e, ao mesmo tempo, compromete a comunidade com o Plano, por meio do envolvimento direto e pela coresponsabilização dos atores-chave.

Há, ainda, claras vantagens na integração de mecanismos participativos no processo de revisão do Plano Diretor, dado que funcionam como um instrumento de aperfeiçoamento das metodologias de planeamento e de qualificação das práticas de gestão territorial. Esta que é suscetível de conduzir a melhores soluções técnicas e a decisões mais fundamentadas em matéria de ordenamento do território e de urbanismo. 


\section{REFERÊNCIAS}

AMARAL, D. F. Direito do Urbanismo - Sumários. Lisboa: Faculdade de Direito da Universidade de Lisboa, 1993.

AMIN, Z. Q_Methodology: A journey into the subjectivity of human mind. Singapore Medical Journal, 41(8), 410-414, 2000.

BROWN, S. R. Q Methodology and qualitative research. Qualitative Health Research, 6 (4), 561-567, 1996.

CASTELLS, M. Communication power. Oxford: Oxford University Press, 2011.

CASTELLS, M. Networks of outrage and hope: Social movements in the internet age. Cambridge: Polity Press, 2012.

CACCIARI, M. A Cidade. Barcelona: Ed. Gustavo Gili, 2010.

CELLAMARE, C. Cities and Self-organization. Tracce Urbane. Rivista Italiana Transdisciplinare di Studi Urbani, 2(3). https://doi.org/10.13133/25326562_2.3.14298, 2018.

CURRY, R.; BARRY, J.; McCLENAGHAN, A. Northern Visions? Applying Q methodology to understand stakeholder views on the environmental and resource dimensions of sustainability. Journal of Environmental Planning and Management, v. 56, n. 5), p. 624-649, 2012.

DAVOUDI, S.; EVANS, N.; GOVERNA, F.; SANTANGELO, M. Territorial governance in the making - Approaches, methodologies, practices. Boletin de la A.G.E v. 46, p. 3352, 2008.

DE BLASIO, E.; KNEUER, M.; SCHÜNEMANN, W.; SORICE, M. The Ongoing Transformation of the Digital Public Sphere: Basic Considerations on a Moving Target. Media and Communication, v. 8, n. 4, p. 1-5, 2020. DOI: 10.17645/mac.v8i4.3639.

EUROPEAN SPATIAL PLANNING OBSERVATION NETWORK (2012) ESPON TANGO Territorial Approaches for New Governance. Interim report.

GASTIL J.; DAVIES, T. Digital Democracy: Episode IV -- A New Hope, how a Corporation for Public Software Could Transform Digital Engagement for Government and Civil Society. Digital Government: Research and Practice (DGOV), v. 1, n. 1: fev. 2020. https://arxiv.org/abs/1910.08604, 2020.

GIL, F. S.; GUIMARÃES, M. H. Avaliação de atitudes e valores de agentes de Desenvolvimento Regional. Metodologia Q. In: COSTA, J. S.; DENTINHO, T.; NIJKAMP, P. (coords.). Compêndio de economia regional: Métodos e técnicas de análise regional. Princípia, 2011, p. 643-662.

HARVEY, D. The Right to the City, New Left Review 53 sept oct 2008. p. 23, 2008. 
INTERREG EUROPE 2021-2027. Cooperation Programme document, March 2021, updated draft version 4. In: Annex of the European territorial cooperation Regulation - General Secretariat of the Council - V 11.12.2020.

LAVEDAN, P. Géographie des Villes. Paris: Librairie Gallimard, 1959.

MARQUES, C. A. et al. Relatório de Fundamentação do Plano Diretor Municipal da Golegã, Câmara Municipal da Golegã, 2021.

MARQUES, C et al. A Cidade que se planeia, pp. 33-50, cap. in Rios, M. e Carvalho, N. T. (coord.). In Direitos Humanos e Democracia em Construção: Desafios Atuais. Belo Horizonte: Conhecimento Editora, 2020.

MOTTA, R. D. Una Aproximación a las Transformaciones de la Ciudadanía y las Ciudades como Condiciones de Posibilidad de la Democracia. Revista Complejidad, Edición Número 13 - Oct./Dic. 2011 y Edición Número 14 - Enero / Marzo 2012. www.complejidad.info, 2011.

ROBBINS, P.; KRUEGER, R. Beyond bias? The promise and limits of $Q$ method in human geography. The Professional Geographer, v. 52, n. 4, p. 636-648, 2000.

SAINT MARC, P. Economia Bárbara. Lisboa: Editora Piaget, 1996.

STEPHENSON, W. The study of behavior, Q technique and its methodology. Chicago: University of Chicago Press, 1953.

STEPHENSON, W. Definition of opinion, attitude and belief. Psychological Record, 15, p. 281-288, 1965.

THE NEW LEIPZIG CHARTER. The transformative power of cities for the common good, Adopted at the Informal Ministerial Meeting on Urban Matters on 30 November 2020. European Commission.

WEBLER, T.; TULER, S.; KRUEGER, R. What Is a Good Public Participation Process? Five Perspectives from the Public. Environmental Management, v. 27, n. 3, p. 435450, 2001.

WEBLER, T.; DANIELSON, S.; TULER, S. Using Q method to reveal social perspectives in environmental research. Greenfield MA: Social and Environmental Research Institute. www.serius.org/pubs/Qprimer.pdf, 2009. 